\title{
Anatomical adaptations to different soil moisture contents in palisade grass and smooth pigweed
}

\author{
Daniel Valadão Silva ${ }^{1 *}$, Cassia Michelle Cabral ${ }^{2}$, Evander Alves Ferreira $^{2}$, Felipe Paolinelli de Carvalho ${ }^{3}$, \\ José Barbosa dos Santos², Jeferson Luiz Dallabona Dombroski ${ }^{1}$
}

10.1590/0034-737X201865040002

\begin{abstract}
Weed adaptations to different environments contribute to their success in establishing in different agroecosystems. A greenhouse and laboratory study was carried out to evaluate the effects of different levels of soil moisture on the anatomical characteristics of two weed species. The treatments were arranged in a 2 x 5 factorial design, with the first factor representing the weed species (Amaranthus hybridus and Brachiaria brizantha) and the second factor being the soil moisture levels in which they were grown $(100 \%, 80 \%, 74 \%, 67 \%$, and $60 \%$ of field capacity). At 55 days after weed emergence, the material for anatomical evaluations was collected. The water stress affected the two weed species differently, causing changes both in the thickness of the tissues evaluated and in their proportions. These changes seem to be related to how each species tolerates water stress. A. hybridus showed thickening of all leaf tissue and change in the proportion of these tissues, whereas B. brizantha showed a decrease in thickness of the leaf tissue and an increase in the proportion of adaxial epidermal and parenchymal tissues.
\end{abstract}

Keywords: weed; leaf anatomy; Amaranthus hybridus; Brachiaria brizantha.

\section{RESUMO}

\section{Adaptações anatômicas de braquiária e caruru em resposta a diferentes níveis de umidade no solo}

As adaptações das plantas daninhas às diferentes condições ambientais contribuem para seu sucesso no estabelecimento de diferentes agroecossistemas. Um trabalho de casa de vegetação e laboratório foi realizado para avaliar os efeitos de diferentes níveis de umidade do solo nas características anatômicas de duas espécies de plantas daninhas. Os tratamentos foram arranjados em esquema fatorial 2 × 5 , sendo o primeiro fator correspondente as espécies de plantas daninhas (Amaranthus hybridus e Brachiaria brizantha), e o segundo aos níveis de umidade no solo em que foram cultivadas $(100 \%, 80 \%, 74 \%, 67 \%$ e 60\% da capacidade de campo). Aos 55 dias após a emergência das plantas daninhas o material foi coletado para as avaliações anatômicas. O déficit hídrico afetou de maneira diferenciada as duas plantas daninhas, provocando alterações tanto na espessura dos tecidos avaliados quanto nas suas proporções. Estas alterações podem estar relacionadas à forma como cada espécie tolera a deficiência de água. $\mathrm{O} A$. hybridus teve espessamento de todos os tecidos da lâmina foliar, além da mudança na proporção desses tecidos, enquanto que a $B$. brizantha teve decréscimo na espessura dos tecidos da lâmina foliar e aumento na proporção de parênquima homogêneo e epiderme adaxial.

Palavras-chave: plantas daninhas; anatomia foliar; Amaranthus hybridus; Brachiaria brizantha.

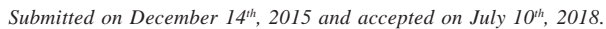

'Universidade Federal Rural do Semi-Árido, Departamento de Ciências Vegetais, Rio Grande do Norte, Brazil. danielvaladaos@yahoo.com.br; jeferson@ufersa.edu.br

${ }^{2}$ Universidade Federal dos Vales do Jequitinhonha e Mucuri, Departamento de Agronomia, Minas Gerais, Brazil. mtchells@yahoo.com.br; jbarbosasantos@yahoo.com.br; evanderalves@yahoo.com.br

${ }^{3}$ Universidade Federal de Viçosa, Departamento de Fitotecnia, Minas Gerais, Brazil. felipepaolinelli@yahoo.com.br

*Corresponding author: danielvaladaos@yahoo.com.br 


\section{INTRODUCTION}

The success of a weed species in the colonization of agroecosystems will depend on its adaptive capacity to different environmental conditions. Among the environmental factors required for plant growth, water is one of the most limiting factors in agricultural systems and is often the target of competition between crop species and weeds.

Each weed species varies in its ability to respond to changes in water availability. In general, water stress induces anatomical, physiological, and biochemical changes in plant tissues, with intensity depending on the species and the intensity and duration of the water deficit. The first plant adaptation strategy to water stress conditions is that the shoot is reduced in favor of the roots, limiting its capacity to compete for light because of the decrease in leaf area and a consequent reduction in productivity (Taiz \& Zeiger, 2009).

Studies on the effects of water deficit on plants have been mainly concentrated on changes in the stomatal opening that act to minimize water losses by transpiration and limit $\mathrm{CO}_{2}$ absorption for the photosynthesis (Reddy et al. 2004; Shao et al., 2008). Severe water stress can affect the enzymatic activity of processes linked to photosynthesis by changes in the metabolism (Baker \& Rosenqvist, 2004; Santos et al., 2006; Ribeiro et al., 2008). In addition, there are also effects on mineral nutrition (Firmano et al., 2009; Gonzalez-Dugo et al., 2010), cell growth (Chaves et al., 2009), and on the plant itself (Shao et al., 2008; Bengough et al., 2011). Anatomical effects are usually neglected in studies of water stress response (Kulkarni et al., 2008).

The anatomical changes caused by low water availability in the environment are generally involved in the protection of plants against loss of water to the environment and desiccation of cortical cells, as well as the maintenance of water transport in xylem (Shao et al., 2008, Chaves et al., 2003).

Smooth pigweed (Amaranthus hybridus L.) and palisade grass (Brachiaria brizantha Stapf) stand out among the most frequent weed species in Brazil (Oliveira \& Freitas, 2008; Trucco \& Tranel, 2011; Borghi et al., 2008). They are found in systems subject to both low and high abiotic stress. However, there is little information on the adaptive mechanisms of these species to different environmental conditions, such as water availability in the soil.

From the foregoing, therefore, the objective of this study was to evaluate the effects of water deficit on the anatomical characteristics of $A$. hybridus and B. brizantha.

\section{MATERIALAND METHODS}

In the greenhouse, the experiment was carried out under controlled temperature and relative humidity. A typical Dystrophic Red-Yellow Latosol, clay texture (56\% clay, 6\% silt, and $38 \%$ sand), was used as substrate. The soil chemical characteristics were as follows: $\mathrm{pH}$ (water) 5.4; organic matter 1.8 dag kg-1 $^{-1} \mathrm{P}, \mathrm{K}, \mathrm{Ca}, \mathrm{Mg}, \mathrm{Al}, \mathrm{H}+\mathrm{Al}$, and Effective CEC of $1.4 ; 10 ; 0.5 ; 0.2 ; 0.4 ; 4.4 ;$ and $1.7 \mathrm{cmol}_{\mathrm{c}} \mathrm{dm}^{-}$ ${ }^{3}$, respectively. The substrate was amended with $300 \mathrm{~kg} \mathrm{ha}^{-}$ ${ }^{1}$ dolomitic limestone; $220 \mathrm{~kg} \mathrm{ha}^{-1}$ single superphosphate; and $40 \mathrm{~kg} \mathrm{ha}^{-1}$ potassium chloride.

The experiment was arranged in a randomized block design, with four replications. The treatments were arranged in the 2 x 5 factorial design, with the first factor corresponding to the weed species, smooth pigweed $(A$. hybridus) and palisade grass (B. brizantha), and the second factor to the levels of soil moisture in which the species were grown (level $1=100 \%$ field capacity $(\mathrm{FC})$; level $2=$ $80 \%$ FC; level $3=74 \%$ FC: level $4=67 \%$ FC; and level $5=$ $60 \% \mathrm{FC}$ ). Each pot filled with $10 \mathrm{dm}^{3}$ of substrate corresponded to an experimental unit.

Field capacity was calculated based on the water retention analysis as a function of the soil matric potential. According to Salassier et al. (2006), the water content of soil at field capacity can be assumed as corresponding the potential of $-1 \mathrm{mWC}$ for clay soils. Thus, the level of $100 \%$ field capacity was standardized at this potential and the other FC levels were standardized by reductions in the soil moisture, which were established by previous experiments.

Five seeds of each species were planted in each experimental unit, and after the emergence, the seedlings were thinned to one plant per pot. The experimental units were irrigated twice a day to adequate the required moisture content. With this purpose, before each irrigation, the pots were weighed and added with the adequate amount of water to reach the required moisture content.

At 55 days after the weed emergence the plants were collected for anatomical evaluations. Fully expanded leaves were collected from the fourth node of the main branch of smooth pigweed and the third leaf from the base to the apex of the central tiller of palisade grass.

The leaves collected were immediately preserved in FAA solution [formaldehyde/acetic acid/70\% alcohol ( 0.5 : 0.5: $9.0 \mathrm{v} / \mathrm{v})]$ and transferred to $70 \%$ ethanol. Anatomical cross-sections were performed by hand using a blade, in the middle of the leaf, and stained with $0.5 \%$ Alcian blue in $2 \%$ tartaric acid and $0.05 \%$ fuchsin. All sections were mounted onto glycerinated gelatin slides and cover slips. Some sections were photographed and analyzed by the IMAGE PRO-PLUS ® Software.

The following characteristics were evaluated: thickness of leaf blade, adaxial epidermis, palisade parenchyma, and adaxial epidermis; the proportion of each tissue in the leaf blade by measuring in an area between two bundles in the region between the main vein and leaf margin, then calculating the percentage of area of each tissue in relation to the total area photographed in the anatomical sections. 
The tissues corresponded to adaxial epidermis, palisade parenchyma, bundle sheath cells, vascular bundles, and abaxial epidermis.

Means of quantitative data were plotted with their respective standard errors.

\section{RESULTS AND DISCUSSION}

A. hybridus showed leaf blade mean thickness of approximately $220 \mu \mathrm{m}$ (Figure 1A). The epidermis is uniseriate, with the adaxial face thicker than the abaxial face (Figure 1C and D). Mesophyll is homogeneous, average of $160 \mu \mathrm{m}$ in thickness (Figure $1 \mathrm{~B}$ ). Vascular bundles present Kranz anatomy (Figures 3A and B), typical of plants with $\mathrm{C} 4$ metabolism. Similar results were reported by Ferreira et al. (2003) for Amaranthus deflexus, with leaves $149.50 \mu \mathrm{m}$ thick on average, simple epidermis, adaxial face also thicker than the abaxial face, and mesophyll with 116.80 $\mu \mathrm{m}$ in thickness on average.

A. hybridus showed increase in leaf blade thickness with increase of water deficit (Figure 1A). No difference was found in the reduction of field capacity from $100 \%$ to $80 \%$, and from this point onwards, there was a tendency to increase the leaf blade thickness up to $67 \%$ of the field capacity. The same as for the leaf blade, there was increase
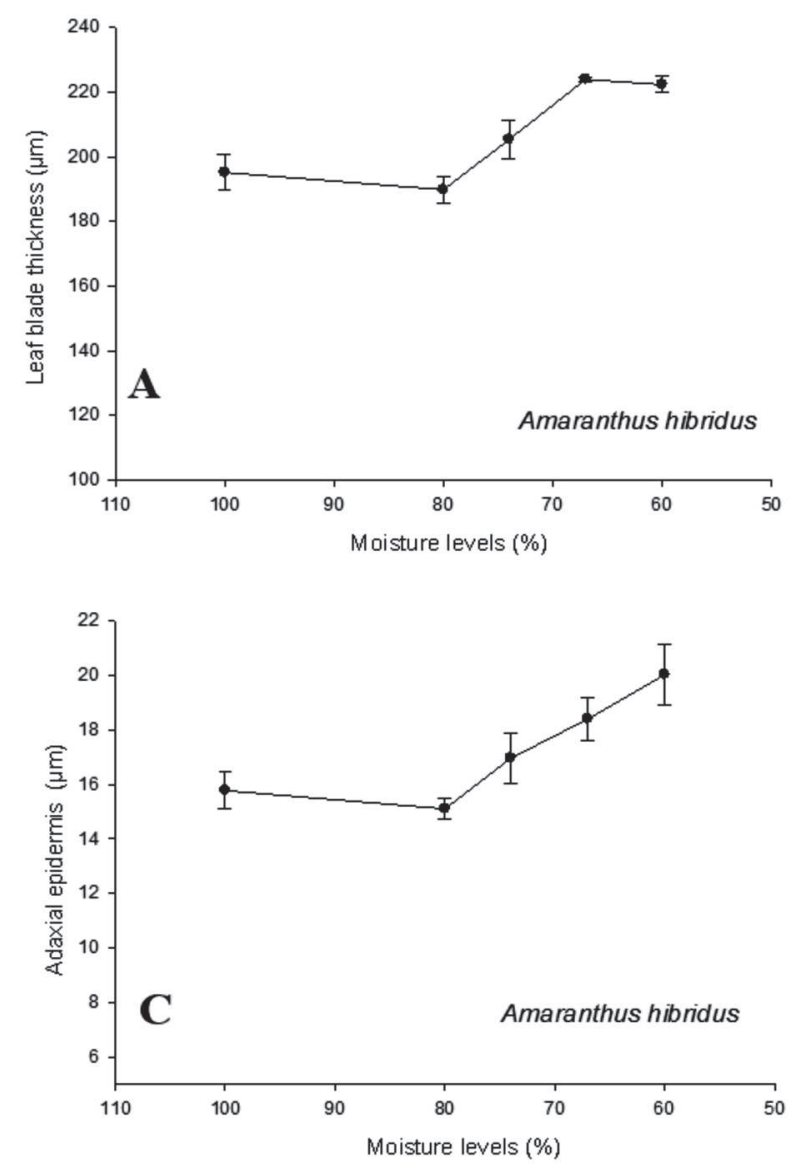

Figure 1: Leaf blade thickness (A), homogeneous parenchyma (B), adaxial epidermis (C), and abaxial epidermis (D) of Amaranthus hybridus leaf grown at different soil moisture levels. $\mu$

Rev. Ceres, Viçosa, v. 65, n.4, p. 306-313, jul/ago, 2018 in the thickness of parenchyma, adaxial epidermis, and abaxial epidermis with increase of water deficit (Figures 1 B, C and D). Increased thickness of leaf and leaf tissues is considered xeromorphic adaptations (Ristic \& Cass, 1991). It is worth noting that the parenchyma of branches, roots, and leaves are important water reservoirs (Zweifel, et al., 2001, Ogburn \& Edwards, 2012, Scholz et al. 2007.

The leaves of A. hybridus showed a gradual decrease in the proportions of adaxial epidermis, abaxial epidermis, and bundle sheath cells with the reduction in soil moisture (Figures 2A , C and D). We also observed a marked reduction in the proportion of vascular bundles in the leaf blade of $A$. hybridus with the reduction in moisture from $100 \%$ to $80 \%$, from which point the decrease was more gradual (Figure 2E). In contrast to the other tissues of $A$. hybridus, the proportion of parenchyma increased with the reduction of water supply (Figure 2B). The decrease in the proportion of the different tissues is possibly due to the decrease in cell size in response to water stress (Lukovik, 2009, Zhang et al., 2012), which is a common phenomenon. On the other hand, the increase in thickness of the parenchyma is a characteristic that has been related to tolerance to osmotic (Rajabpoor et al., 2014) and water stress (Kulkarni et al., 2008, Guha et al., 2010).
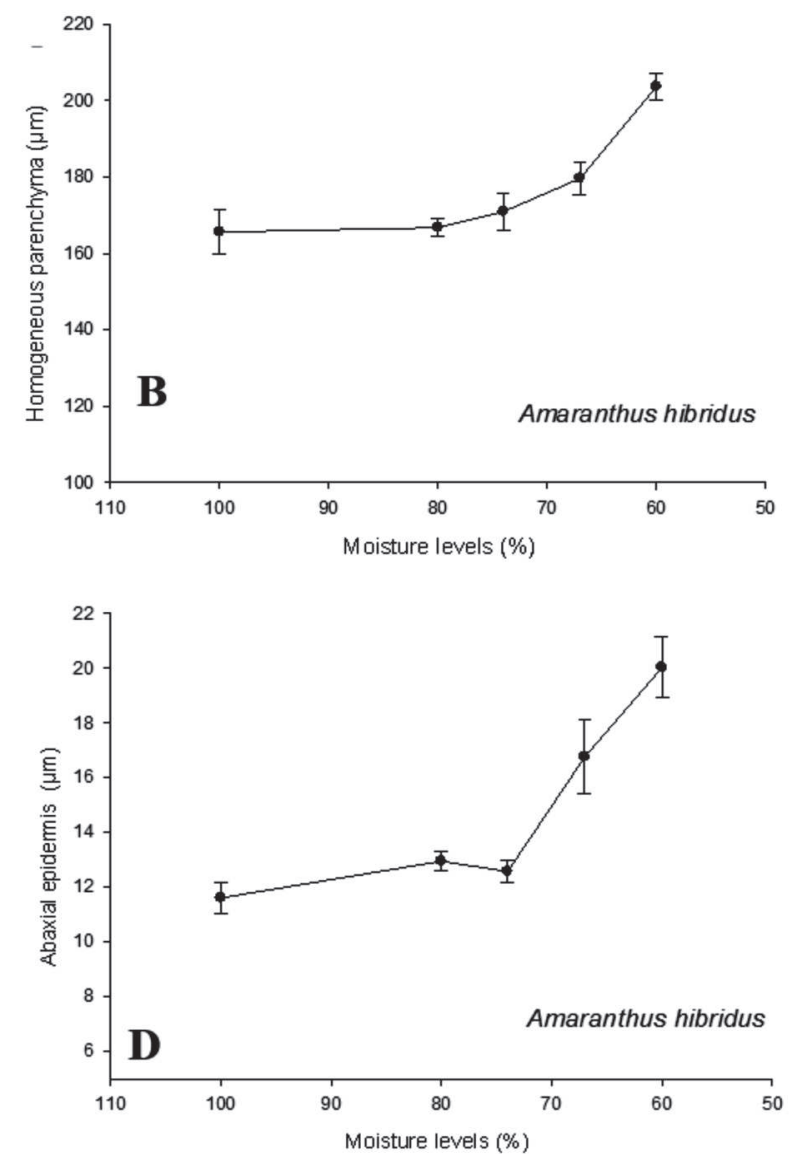
Thus, the increase in leaf thickness is the result of an increase in thickness of epidermis and parenchyma, and the increase of parenchyma was more pronounced, in terms of proportion. The increase in parenchyma thickness seems to be associated with the increase of both photosynthetic efficiency and water use efficiency (Kulkarni et al., 2008), which is responsible for the initial capture of atmospheric $\mathrm{CO}_{2}$ by $A$. hybridus due to its $\mathrm{C} 4$ metabolism. $\mathrm{CO}_{2}$ is transported to bundle sheath cells where it is definitly captured in the Calvin-Benson cycle. Interestingly, the water restriction caused a proportional increase in the parenchyma and a decrease in vascular tissues, including the sheath (Figure $2 \mathrm{~B}$ and D). The reduction in the conduction capacity is, unlike that observed for the parenchyma, an indicator of lack of tolerance to water stress.

The quantitative anatomy study of $B$. brizantha leaf blades, from the apical region, by Alves de Brito et al. (2004) showed different results from the present study, with
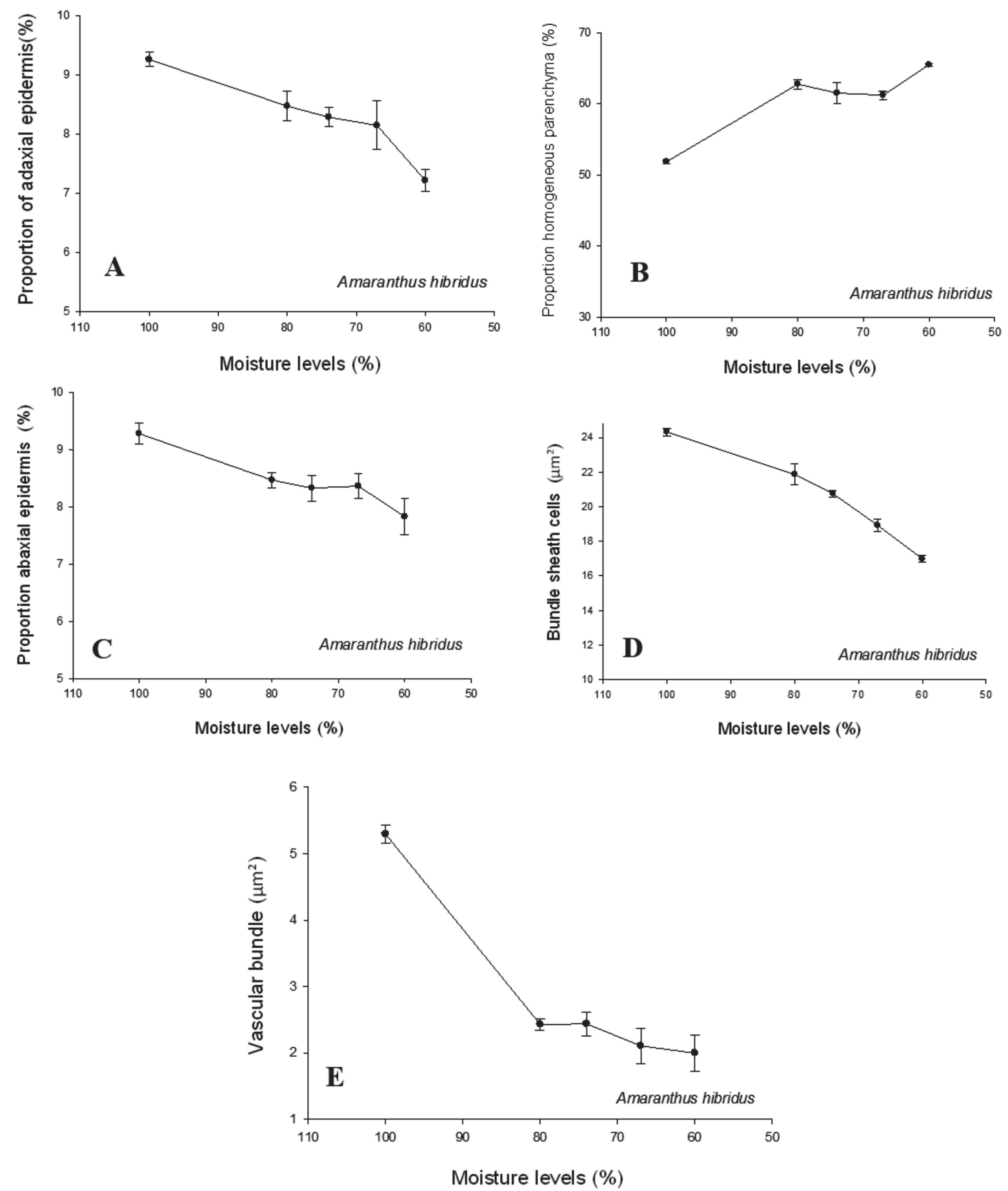

Figure 2: Proportion of adaxial epidermis (A), proportion homogeneous parenchyma (B), abaxial epidermis (C), bundle sheath cells (D), and vascular bundle (E) of Amaranthus hybridus leaf grown at different soil moisture levels. 
approximately $23 \%$ epidermis (including buliform cells), about $35 \%$ of parenchyma, $29 \%$ of parenchymal sheath, and $12 \%$ of xylem, phloem, and sclerenchyma together.

Blade leaf thickness of $B$. brizantha decreased with reduction in soil moisture to $70 \%$ of field capacity (Figure 5A). The internal tissues of B. brizantha leaf blade such as adaxial epidermis, vascular bundles, and abaxial epidermis also showed reduction in thickness (Figures 5 B, D and E). However, the vascular bundle sheath showed no significant variation with decrease in soil moisture (Figure 6D), which is similar to what is observed in plants with low tolerance to water stress (Zhang et al., 2012; Ristic \& Cass, 1991). As discussed earlier, the reduction in thickness of leaf tissues is possibly related to the decrease in cell size. However, in the case of $B$. brizantha, in contrast with $A$ hybridus, there was a decrease in leaf thickness with the reduction in water availability, and a great reduction in parenchyma thickness, which is commonly associated with water stress intolerance (Ristic \& Cass, 1991).
The water deficit caused an increment in the proportion of adaxial epidermis of $B$. brizantha leaf blade (Figure 6A). However, the proportion of parenchyma increased and the proportion of bundle sheath cells decreased with soil moisture reduction (Figures $6 \mathrm{~B}$ and $\mathrm{C}$ ). In B. brizantha, the proportion of vascular bundles and abaxial epidermis were not affected by the reduction in water supply (Figures $6 \mathrm{D}$ and $\mathrm{E}$ ). It is interesting that the thickness of epidermal cells on the adaxial surface of B. brizantha had a significant decrease with the reduction of moisture in the soil at the same time that an increase occurred in the proportion of this tissue. Considering that the bulliform cells were measured together with the epidermis, we can infer that there was a reduction in the proportion and thickness of the epidermal cells, but an increase in the proportion of bulliform cells in response to water deficiency. Bulliform cells have thin walls and thin or no cuticles, thus they lose water by transpiration more quickly than other epidermal cells. As the turgor pressure decreases in the
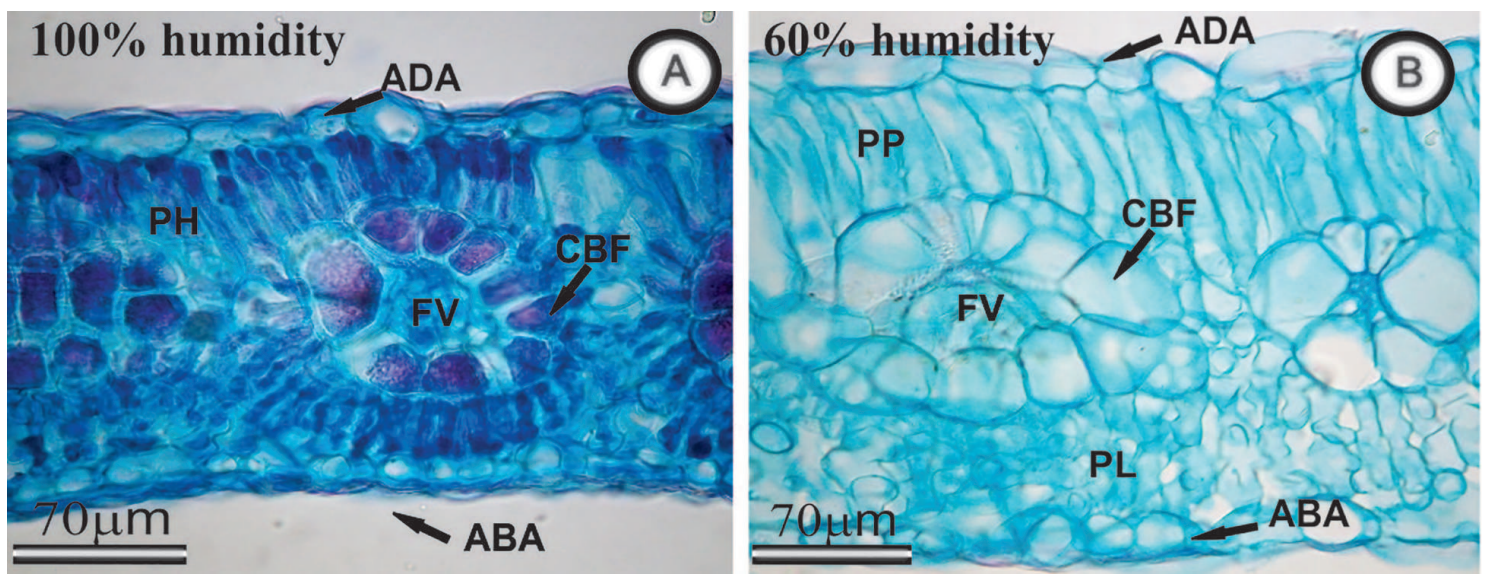

Figure 3: Cross section of leaf blade of smooth pigweed (Amaranthus hybridus) grown under 100\% field capacity (A) and 60\% field capacity (B). ADA: adaxial epidermis; ABA: abaxial epidermis; PH: homogeneous parenchyma; FV: vascular bundles; CBF: bundle sheath cells; PP: palisade parenchyma; and PL: spongy parenchyma.
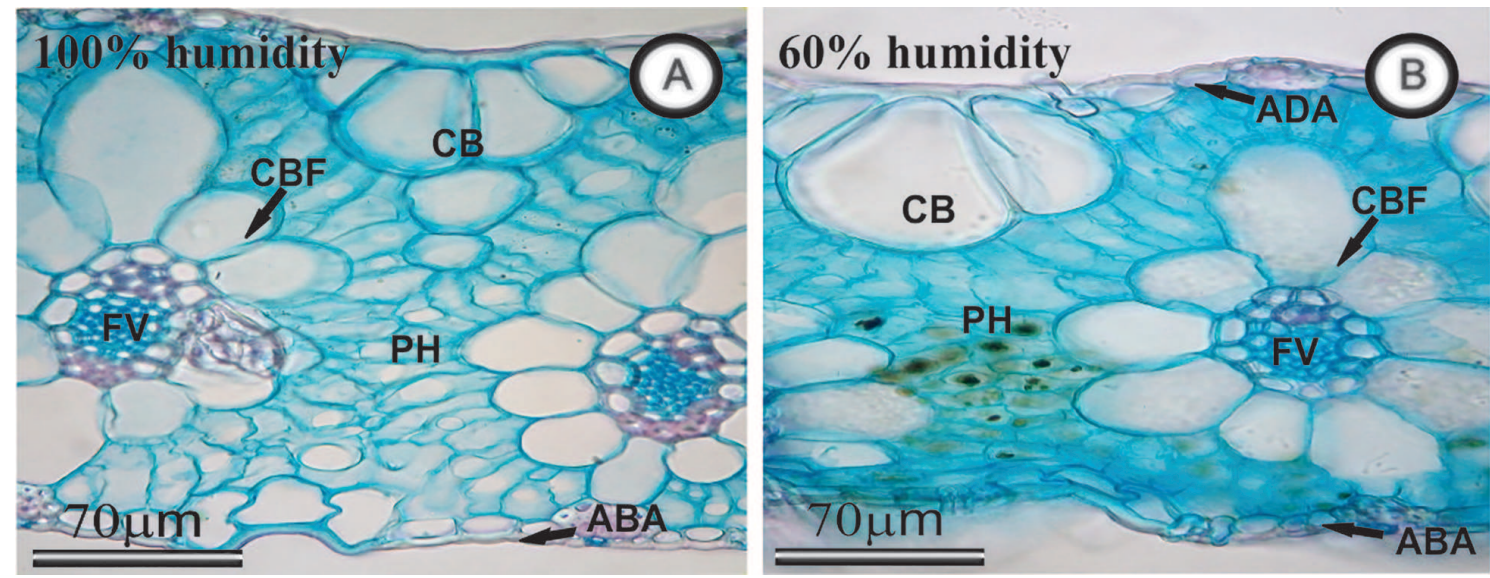

Figure 4: Cross section of leaf blade of palisade grass (Brachiaria brizantha) grown under 100\% field capacity (A) and $60 \%$ field capacity (B). ADA: adaxial epidermis; ABA: abaxial epidermis; PH: homogeneous parenchyma; FV: vascular bundles; CBF: bundle sheath cells; CB: buliform cells; PP: palisade parenchyma; and PL: spongy parenchyma. 
bulliform cells, the maintenance of the turgor pressure in the cells on the abaxial (lower) side causes leaves to roll up. The increase in size of bulliform cells in response to water stress is considered an indicator of adaptation to stress (Ristic \& Cass, 1991), but it is an escape mechanism, that is, it favors the maintenance of water content in the leaf, but impairs photosynthesis.

Figures 3 and 4 show the visual effect of the water deficit in the two species evaluated, with the increase in leaf thickness of $A$. hybridus and the decrease in in leaf thickness of B. brizantha. According to Shao et al. (2008), to avoid
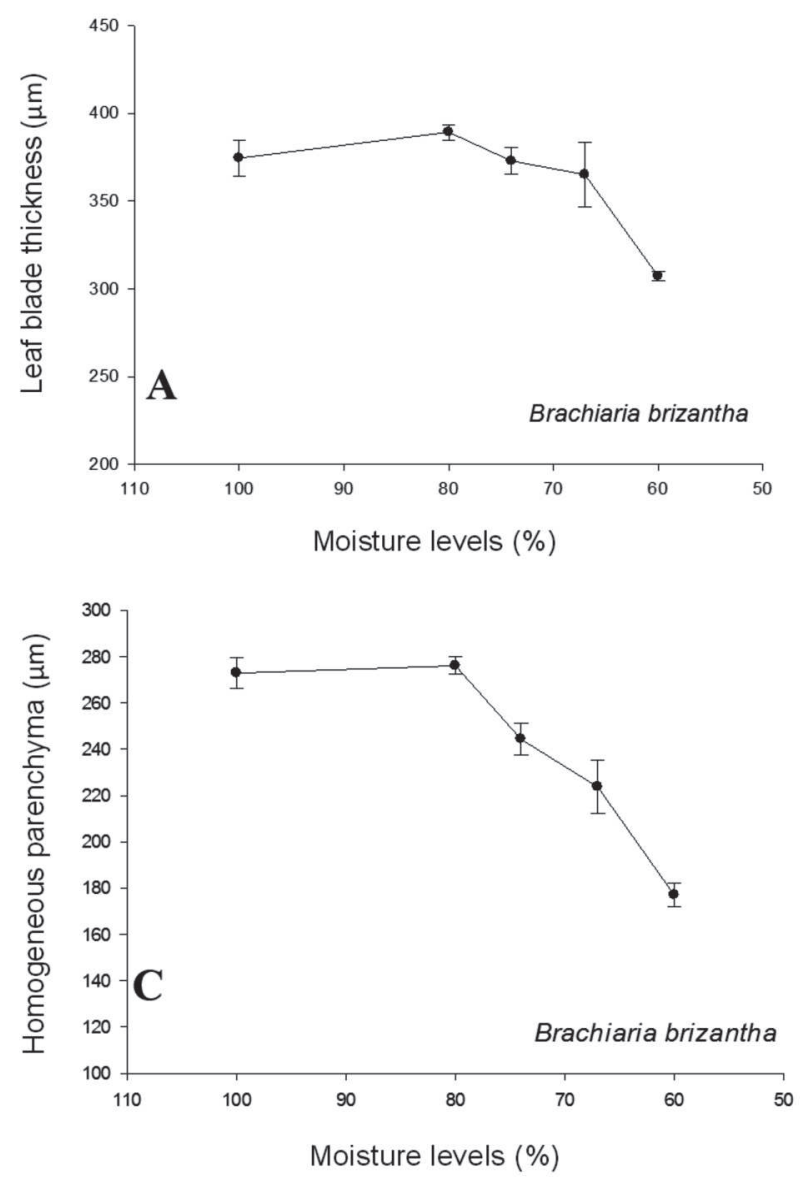

desiccation, plants under water stress increase the conduction capacity by enlarging the rib region and reducing the transport distance. Thus, the reduction of vascular bundle size in stressed plants, as observed in B. brizantha, is an indicator of susceptibility; however the increase in tissue thickness constitutes a xeromorphic characteristic and predicts xerophytic environmental conditions. In addition, this feature may be useful because it reflects excess irradiance on the leaves (Cao, 2000) and consequently distributes the light more uniformly to chloroplasts, optimizing photosynthesis (Vogelmann \& Martin, 1993).
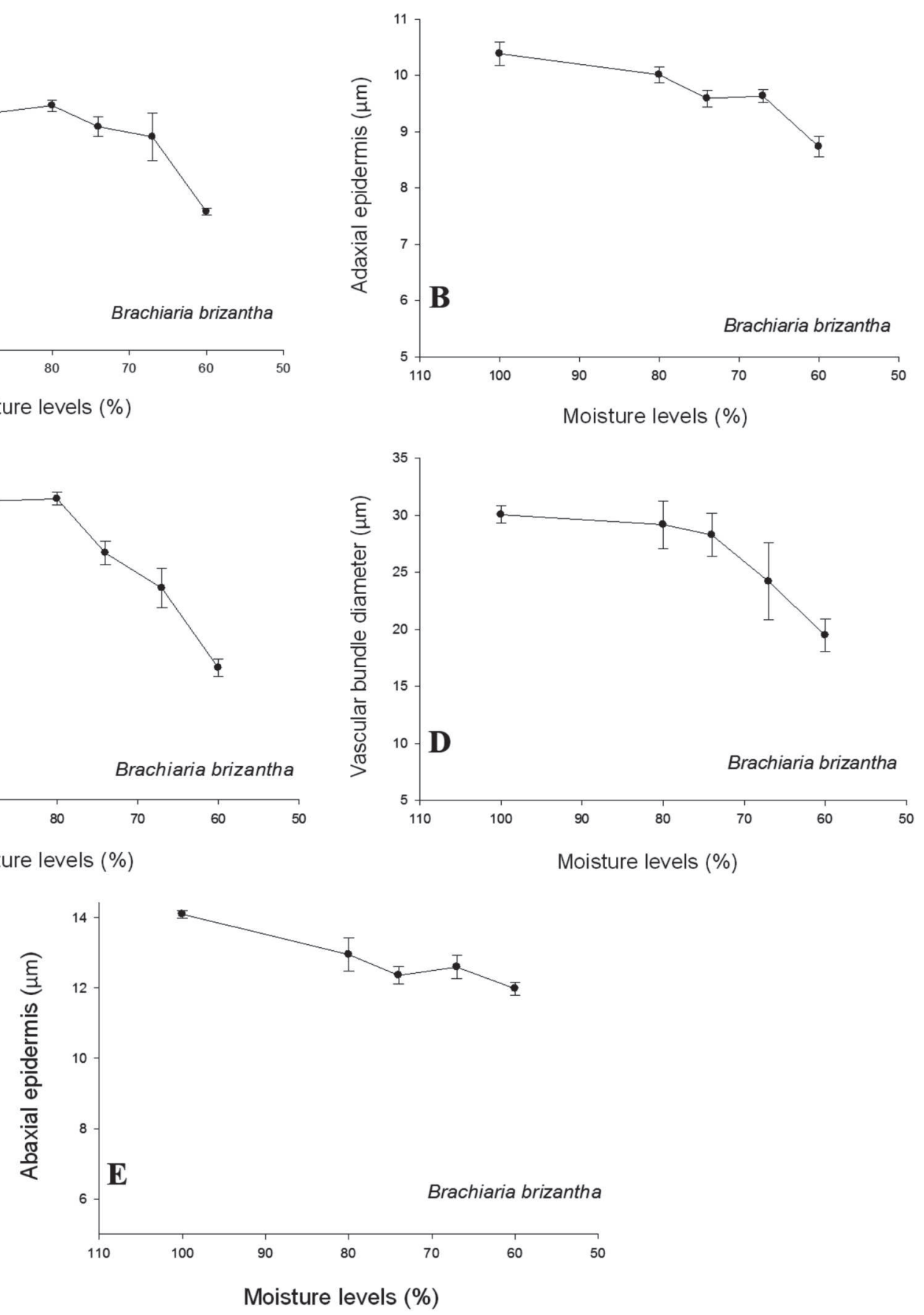

Figure 5: Leaf blade thickness (A), adaxial epidermis (B), homogeneous parenchyma (C), vascular bundle diameter (D), and abaxial epidermis thickness (E) of leaves of Brachiaria brizantha grown at different soil moisture levels. 

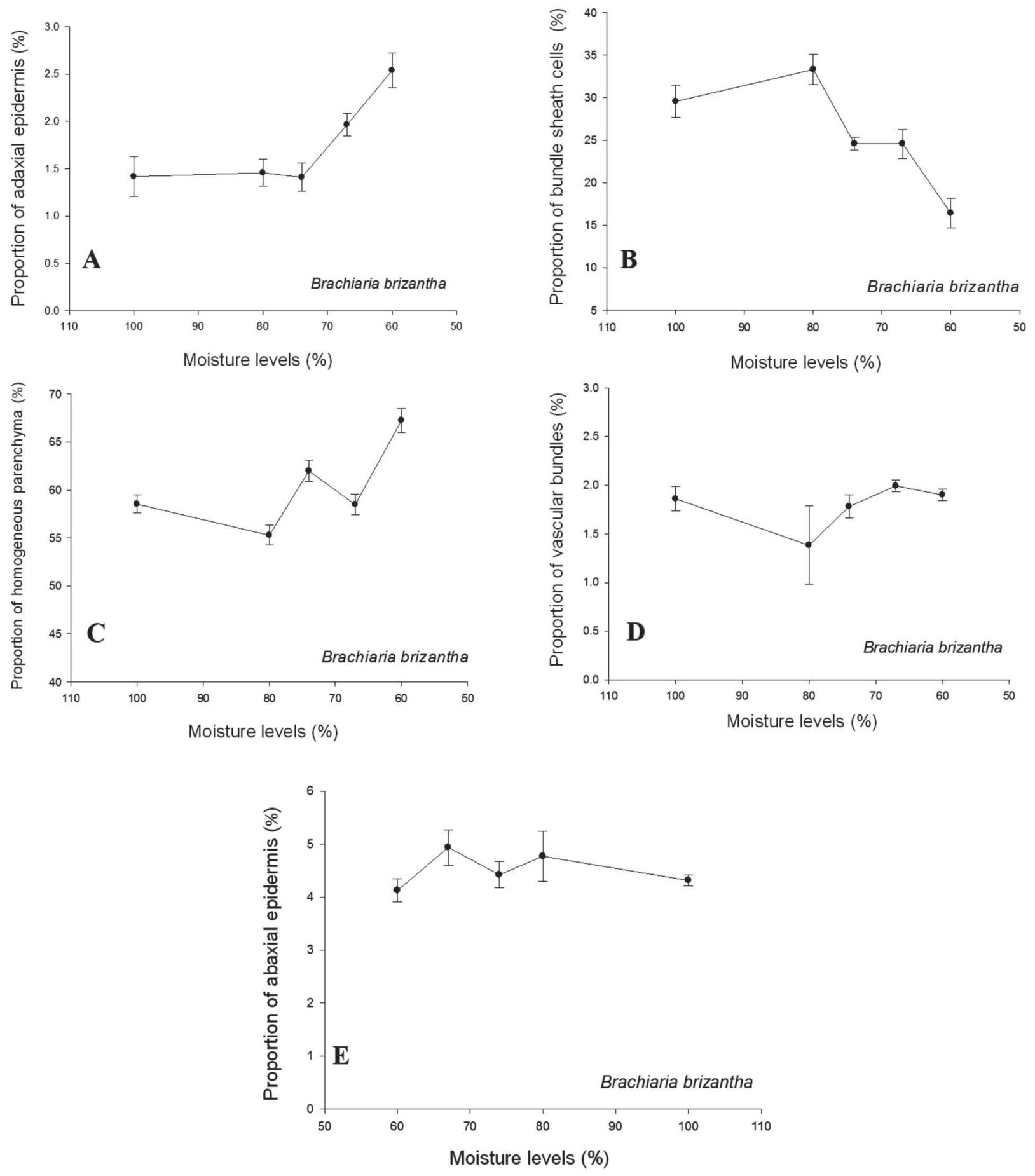

Figure 6: Proportion of adaxial epidermis (A), bundle sheath cells (B), homogeneous parenchyma (C), vascular bundles (D), and abaxial epidermis (E) of leaves of Brachiaria brizantha grown at different soil moisture levels.

Changes caused by water stress are related to other stress factors, such as high temperatures and excess solar radiation. Coffee plants subjected to high radiation intensity, without shading, for example, had greater leaf blade thickness, which is typical of sun leaves, responding primarily to water limitation due to excess temperature (Nascimento et al., 2006). These characteristics tend to minimize heating by increasing the thickness of the chlorophyll parenchyma, with the purpose of absorbing, channeling and dispersing the light, not interfering with the leaf activities (Batista et al., 2010).

\section{CONCLUSIONS}

Different soil moisture levels affected weed species differently, causing changes in both the thickness of the tissues analyzed and their proportions. 
A. hybridus showed thickening of all leaf blade tissues and changes in their proportions, standing out the increase in the proportion of the parenchyma.

B. brizantha showed decrease in thickness of leaf blade tissues even though it also showed increase in the proportion of parenchyma.

\section{ACKONOWLEDGEMENTS}

The authors thank the Coordination of Improvement of Higher Education Personnel (CAPES), the National Council for Scientific and Technological Development (CNPq), and the Foundation for Research Support of the State of Minas Gerais (FAPEMIG) for the financial support to this research project.

\section{REFERENCES}

Alves de Brito CJF, Rodella RA \& Deschamps FC (2004) Anatomia quantitativa da folha e do colmo de Brachiaria brizantha (Hochst. ex A. Rich.) Stapf e B. humidicola (Rendle) Schweick. Revista Brasileira de Zootecnia, 33:519-528.

Baker NR \& Rosenqvist E (2004) Applications of chlorophyll ûuorescence can improve crop production strategies: an examination of future possibilities. Journal of Experimental Botany, 55:1607-1621.

Batista LA, Guimarães RJ, Pereira FJ, Carvalho GR \& Castro EM (2010) Anatomia foliar e potencial hídrico na tolerância de cultivares de café ao estresse hídrico. Revista Ciência Agronômica, 41:475-481.

Bengough AG, Mckenzie BM, Hallett PD \& Valentine TA (2011) Root elongation, water stress, and mechanical impedance: a review of limiting stresses and beneûcial root tip traits. Journal of Experimental Botany, 62:59-68.

Borghi E, Costa NV, Crusciol CAC \& Mateus GP (2008) Influence of the spatial distribution of maize and Brachiaria brizantha intercropping on the weed population under no-tillage. Planta Daninha, 26:559-568.

Cao KF (2000) Leaf anatomy and chlorophyll content of 12 woody species in contrasting light conditions in a Bornean heath forest. Canadian Journal of Botany, 78:1245-1253.

Chaves MM, Maroco JP \& Pereira JS (2003) Understanding plant responses to drought-from genes to the whole plant. Functional Plant Biology, 30:239-264.

Chaves MM, Flexas J \& Pinheiro C (2009) Photosynthesis under drought and salt stress: regulation mechanisms from whole plant to cell. Annals of Botany, 103:551-560.

Ferreira EA, Procópio SO, Silva EAM, Silva AA \& Rufino RJN (2003) Estudos anatômicos de folhas de espécies de plantas daninhas de grande ocorrência no Brasil: IV - Amaranthus deflexus, Amaranthus spinosus, Alternanthera tenella e Euphorbia heterophylla. Planta Daninha, 21:263-271.

Firmano RS, Kuwahara FA \& Souza GM (2009) Relação entre adubação fosfatada e deficiência hídrica em soja. Ciência Rural, 39:1967-1973

Gonzalez-Dugo V, Durand J \& Gastal F (2010) Water deûcit and nitrogen nutrition of crops. A review. Agronomy and Sustainable Development, 30:29-544.

Guha A, Sengupta D, Rasineni GK \& Reddy AR (2010) An integrated diagnostic approach to understand drought tolerance in mulberry (Morusindica L.). Flora, 205:144-151.
Kulkarni M, Borse T \& Chaphalkar S (2008) Mining anatomical traits: A novel modelling approach for increased water use efficiency under drought conditions in plants. Czech Journal of Genetics and Plant Breeding, 44:11-21.

Lukovik J, Maksimovic I, Zoric L, Nagl N, Percic M, Polic D \& Putnik-Delic M (2009) Histological characteristics of sugar beet leaves potentially linked to drought tolerance. Industrial Crops and Products, 30:281-286.

Nascimento EA, Oliveira LEM, Castro EM, Filho ND, Mesquita AC \& Vieira CV (2006) Alteracoes morfofisiológicas em folhas de cafeeiro (Coffea arabica L.) consorciado com seringueira (Hevea brasiliensis Muell. Arg.). Ciência Rural, 36:852-857.

Ogburn RM \& Edwards EJ (2012) Quantifying succulence: a rapid, physiologically meaningful metric of plant water storage. Plant, Cell \& Enviromental, 35:1533-1542.

Rajabpoor S, Kiani S, Sorkheh K \& Tavakoli F (2014) Changes induced by osmotic stress in the morphology, biochemistry, physiology, anatomy and stomatal parameters of almond species (Prunus L. spp.) grown in vitro. Journal of Forestry Research, 25:523-534.

Reddy AR, Chiatanya KV \& Vivekanandan M (2004) Drughtinduced responses of photosynthesis and antioxidant metabolism in higher plants. Journal of Plant Physiology, 161:1189-1202.

Ribeiro RV, Santos MG, Machado EC \& Oliveira RF (2008) Photochemical heat-shock response in common bean leaves as affected by previous water deûcit. Russian Journal of Plant Physiology, 55:350-358.

Ristic Z \& Cass DD (1991) Leaf anatomy of Zea mays L. in response do water shortage and high temperature: A comparison of drought-resistant and drought-sensitive lines. Botanical Gazette, 152:173-185.

Salassier B, Soares AA \& MantovanI EC (2006) Manual de irrigação. $8^{\mathrm{a}}$ ed. Viçosa, Editora UFV. 625p.

Santos Junior UM, Gonçalves JFC \& Feldpausch TR (2006) Growth, leaf nutrient concentration and photosynthetic nutrient use efûciency in tropical tree species planted in degraded areas in central Amazonia. Forest Ecology and Management, 226:299309.

Scholz FG, Bucci SJ, Goldstein G, Meinzer FC, Franco AC \& MirallesWilhelm F (2007) Biophysical properties and functional significance of stem water storage tissues in Neotropical savanna trees. Plant, Cell \& Enviromental, 30:236-248.

Shao HB, Chu LY, Jaleel CA \& Zhao CX (2008) Water-deficit stress-induced anatomical changes in higher plants. Comptes Rendus Biologies, 331:215-225.

Taiz L \& Zeiger E (2009) Fisiologia Vegetal. $4^{\mathrm{a}}$ ed. Porto Alegre, Art Med. 819p.

Trucco F \& Tranel PJ (2011) Amaranthus In: Kole C (Ed.) Wild Crop Relatives: Genomic and Breeding Resources: Vegetables. Berlin, Springer. p. 11-21.

Oliveira AR \& Freitas SP (2008) Levantamento fitossociológico de plantas daninhas em áreas de produção de cana-de-açúcar. Planta Daninha, 26:34-46.

Vogelmann TC \& Martin G (1993) The functional siginficance of palisade tissue: penetration of directional versus diffuse light. Plant, Cell and Environment, 16:65-72.

Zhang L, Wang Q, Guo Q, Chang Q, Zhu Z, Liu L \& Xu H (2012) Growth, physiological characteristics and total flavonoid content of Glechoma longituba in response to water stress. Journal of Medicinal Plants Research, 6:1015-1024.

Zweifel R, Item H \& Häsler R (2001) Link between diurnal stem radius changes and tree water relations. Tree Physiology, 21:869877.

Rev. Ceres, Viçosa, v. 65, n.4, p. 306-313, jul/ago, 2018 